\title{
Mortgage loans and access to housing for low-income households in Latin America
}

\author{
Gerardo M. Gonzales Arrieta
}

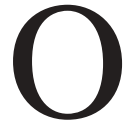

$\mathrm{n}$ the basis of a study on mortgage loan options available in eight Latin American countries, this article identifies two pending tasks for most of the countries: the need to make long-term funds available to mitigate the risk of a mismatch of maturities and rates, and the need to harmonize profitability criteria for lenders with the criterion of access to credit for the low-income population. The paper recommends the creation of linkages between the housing finance market and the capital market through secondary mortgage markets, for which the housing finance market must use instruments other than subsidies. In addition, the paper proposes a number of options to ensure that the State helps to create mortgage markets that will provide the low-income population with better access to housing. 


\section{I}

\section{Introduction}

The financing of housing is a key element of any housing policy. In general, two objectives should be taken into account in order to make finance options viable and sustainable. First, the options should offer profitability to market participants; otherwise, it will not be feasible to attract investment, particularly private investment, to the housing sector. Secondly, they should be adapted to the potential borrowers' ability to pay; otherwise, the low-income population will be marginalized from market operations.

Since these two objectives are not necessarily compatible, the State has at various times become a key player; this has often resulted in a paternalistic approach and an inappropriate allocation of resources -with loans being granted at subsidized interest rates - together with inefficient recovery of funds and serious problems of payment arrears.

Other schemes have also been tried with the aim of making more room for private management in the construction and financing of housing, reserving for the State, at least in theory, the role of basically regulating and subsidizing the purchasing power of the lowerincome strata. To that end, State intervention has focused on the contribution of direct, non-reimbursable subsidies, with the prerequisite of prior savings on the part of beneficiary families. Since this system is frequently inadequate to allow low-income families to purchase the kind of housing they want or can afford, these two sources of financing are supplemented by some type of housing credit.

The provision of mortgage loans on more appropriate terms for low-income families, however, has not been an easy task. In general, institutional schemes for mobilizing resources for housing have not made long-term funds available, although housing finance involves precisely this type of time frame. The availability of short-term funds, basically family savings, has not formed a stable basis for housing finance systems; rather it has created potential - and often real- risks of a mismatch of maturities and rates.

$\square$ This article is an abridged version of a study of the same title published by ECLAC in the Financiamiento del Desarrollo series (ECLAC, 2002). The opinions expressed herein are the exclusive responsibibily of the author.
Moreover, the relatively limited development of capital markets has also had a negative impact by weakening the linkages between these markets and the financing of housing.

Furthermore, the small amounts involved in mortgage loan operations for low-income sectors and the high transaction costs with respect to these amounts has tended, given the competitive scenario, to discourage financial intermediaries from granting mortgage loans to these sectors. In other words, many of the market-based mortgage options are, in practice, mainly available to the higher-income sectors.

This paper proposes a series of considerations on the functioning of available mortgage options in a sample of eight Latin American countries, ${ }^{1}$ and policy recommendations to help develop the housing finance markets and enhance their impact on access to housing, especially for low-income sectors.

Section II below discusses the conceptual aspects of resource mobilization for housing, taking into account various institutional and operational models and considering their implications for the functioning of intermediaries and the management of their risks, on the one hand, and the linkages between housing markets and financial and capital markets, on the other. In view of the dual objective - profitability and accessibility - of any mortgage instrument, and the predominance in Latin America of large population sectors with low purchasing power, a theoretical

\footnotetext{
${ }^{1}$ The countries considered in the study are: Brazil, Chile, Colombia, Costa Rica, Dominican Republic, Ecuador, Mexico and Peru. Besides the availability of information, other criteria used to form the sample were: geographical distribution (five South American, one Central American, one North American and one Caribbean country); economic size (two large countries: Brazil and Mexico; three medium-sized countries: Chile, Colombia and Peru; and three small countries: Costa Rica, Ecuador and Dominican Republic); and institutional aspects that affect the housing sector: (for example, one country, Ecuador, is legally dollarized); another, Peru, is de facto dollarized; three countries (Chile, Colombia and Mexico) currently have indexation systems; one country, Brazil, has some indexation experience; and two countries (Costa Rica and the Dominican Republic) have no indexation tradition. The study also includes an analysis of two other countries - Argentina, an economically large South American country with, until recently, a convertibility system, and Panama, an economically small Central American country with a dollarized system - with regard to the development of secondary mortgage markets.
} 
analysis is made of the contribution of housing subsidies to the demand for easier access to housing.

On the basis of existing institutional mortgage schemes and instruments, section III formulates a series of conclusions and policy recommendations for developing a type of housing finance management that may lead to an efficient and sustainable expansion of mortgage markets, and may also effectively enable low-income sectors to gain access to housing. Special attention is given to the State's role in the development of mortgage markets and the enhancement of access to housing and financing for low-income sectors.

\section{II}

\section{Housing credit: conceptual aspects}

\section{Models for financial resource mobilization for housing}

Housing is a durable good; it is perhaps the most important physical asset for the majority of family units, and its price is usually several times higher than the income of the potential buyers. In most cases, therefore, purchasing a house is only feasible by means of a long-term loan, which enables the buyer to ease the pressure of this high price on family income. The availability of long-term housing credit, however, not only raises questions about its volume in relation to demand, but also about the need for transforming maturities on the part of the originators of these loans.

The most traditional model for mobilizing resources for housing is the one based on intermediation by the financial system (figure 1). It is carried out by multi-spectrum banks or financial institutions - which finance various activities, including housing - or, as was in the past and is still the present case of many Latin American countries, specialized mortgage institutions. As a primary source of funds for this purpose, the latter raise family savings, mainly through relatively short-term deposits.

Loans originated by these institutions remain as assets on their balance sheets for the entire length of the loan. Lending institutions also take charge of administering and collecting payments on these loans. In other words, they perform all the functions of the mortgage process: funding and loan origination and servicing. That these institutions grant long-term loans with short-term savings exposes them to potential risks of mismatch of maturities, and possibly of rates, where ceilings exist on mortgage interest; these risks are concentrated in lending institutions.

In order to attract more funds to the housing sector, taking into account that capital markets have
FIGURE 1

\section{Traditional model of mortgage} intermediation

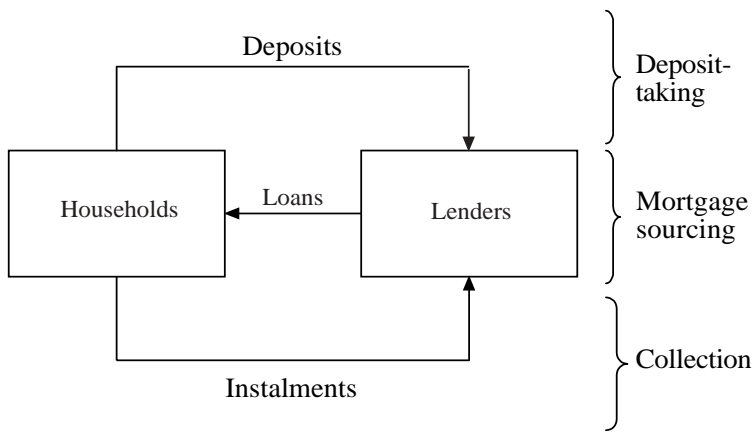

Source: Prepared by author.

new investment agents and more long-term funds available, and in order for the maturities of these resources to match the maturities of the loans they are financing, increasing attention is being paid to an emerging model of resource mobilization. This model is based on the development of a secondary mortgage market, in which mortgages are first sold, generally to agencies that specialize in acquiring mortgages from various lenders, and then issue securities and bonds which are backed by those mortgages; these are then sold to investors (generally institutional investors) in the capital markets (figure 2).

This process of selling of mortgages and their later securitization makes possible, first of all, a faster rotation of the resources being managed by lending institutions, since these assets come off their balance sheets before their maturity, in return for funds to originate new loans and, secondly, the establishment of a linkage between the housing finance and capital markets, which facilitates the transformation of maturities required in the former case. In the more 
FIGURE 2

Movilization of resources for ousing with a secondary market

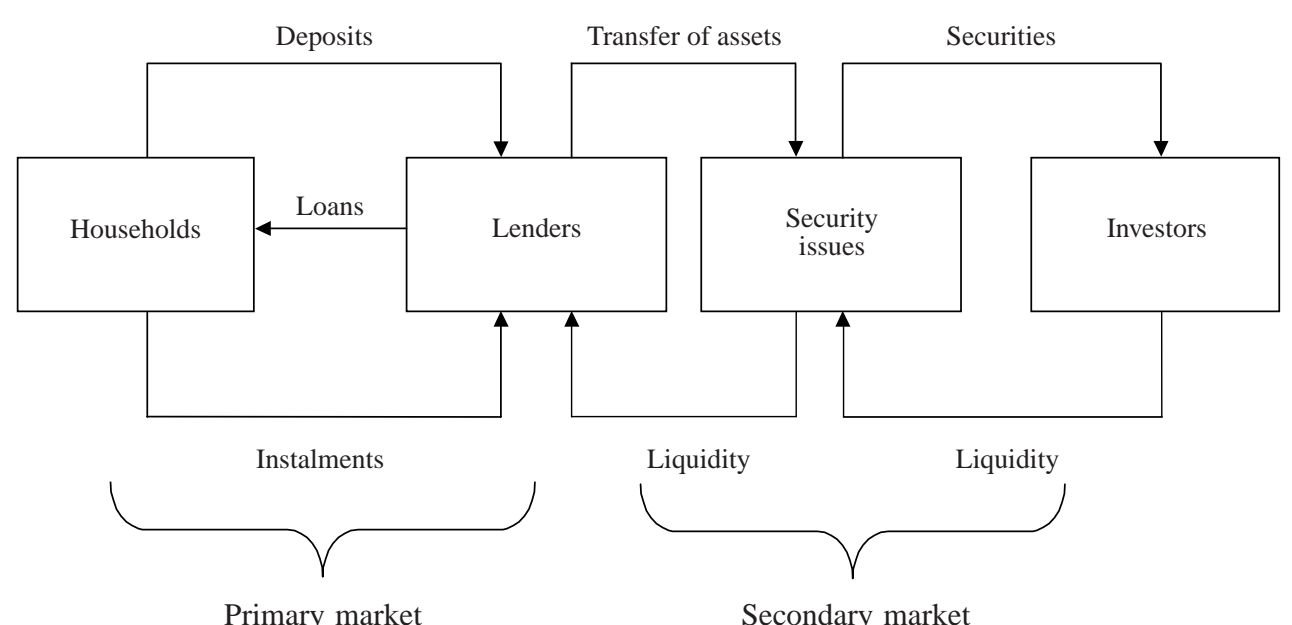

sophisticated version of this model, there is a tendency towards specialization of functions within the mortgage process: the lending institution basically becomes a loan originator, whose risks are transferred and spread to the capital market, diversifying its sources of funds and even transferring loan administration to specialized agencies that may emerge.

Of course, the above description is overly simplified and mainly serves to illustrate the differences between a model of financial intermediation for housing and a model for mobilizing resources backed by a secondary mortgage market. Other variations also exist, both theoretically and practically. One example would be housing funds - generally government funds - to provide resources to lending institutions; the latter, under certain terms, originate mortgage loans that, depending on the degree of development of the markets, could be securitized or not. Another example might be for lending institutions to raise resources through the issue of bonds or other mortgage securities, which would also serve to establish linkages, although less sophisticated ones, with capital markets. ${ }^{2}$ In fact, these and other variations have been used at different times in a number of countries in Latin America.

\footnotetext{
${ }^{2}$ One notable case in the region is the well-developed system of mortgage securities (letras de crédito hipotecario) in Chile; its consolidation was fostered by the pension reform initiated in Chile in 1981, which generated increasing long-term domestic savings, as well as the emergence of life insurance companies as another important institutional investor in these securities.
}

There is certainly a clear trend towards reassessing institutional schemes for mobilizing resources for the housing sector. An attempt is being made to provide a greater volume of residential mortgage loans and, at the same time, to obtain resources on terms of maturity that are compatible with housing finance. There is thus a shift in the traditional model, limited to the financial market, based on the mobilization of short-term family savings for the origination of long-term mortgage loans. But this shift does not mean discarding the traditional model, which will remain important in the great majority of developing countries, but rather complementing it with a scheme for obtaining resources from both the financial market and the capital market, through traditional methods of attracting family savings and mechanisms for raising institutional savings, in order to originate mortgage loans that can be securitized.

Ever since the origination of mortgage loans began to be separated from the mobilization of savings from the public, a trend has been seen towards the attraction of general savings from the economy - whether they be savings deposited in many different banks or in specialized financial institutions, savings administered by institutional investors or even savings from abroad - to channel them in some way to housing finance, through innovative mortgage instruments. ${ }^{3}$ This probably occurs at the expense of the mobilization of compulsory savings specifically allocated for

\footnotetext{
${ }^{3}$ See Hausmann (1998, p. 11).
} 
housing finance, among other reasons because of the constraints it imposes on the amount of resources that can be mobilized in this manner. The emerging scheme described above should help to solve the problem of maturities mismatch and the need to spread risk. ${ }^{4}$

\section{Linkages of housing credit with direct housing subsidies and prior savings}

Housing finance institutions will have to compete for resources in the financial and capital markets. They will therefore require instruments that offer attractive rates of return, to both savers and investors; thus they will need to design mortgage instruments on market terms. This means that housing credit amortizations must permit the recovery of loans in real terms, to enable the financing of a new house and the sale of mortgages on the secondary market. It is argued that subsidizing one family places a burden on 20 savers, who will receive low or even negative rates of return on their deposits, thereby providing a disincentive to saving and hindering the growth of the financial system. ${ }^{5}$

This objective, however, is not necessarily compatible with the possibilities of access to mortgage credit options by potential borrowers, mainly in the low-income segments. The chief obstacle to solving the housing deficit of these sectors has been precisely their difficulty in gaining access to existing finance opportunities, for three basic reasons: (i) their insufficient purchasing power, which prevents them from converting their enormous potential demand into effective demand; (ii) their lack of adequate collateral to qualify for a mortgage loan; and (iii) their inability, especially in countries with large informal sectors, to show evidence of a steady income. The combination of prior saving/mortgage loan is clearly insufficient to enable low-income sectors to gain access to housing, although it may be feasible for the higher-income strata.

Tripartite schemes have emerged to address this problem and facilitate access to housing. Their components are as follows: prior saving on the part of buyers, a State-provided, non-reimbursable demand subsidy and, where appropriate, a complementary mortgage loan on market terms. The main objective of

\footnotetext{
4 This trend can be seen in the contents of some recently introduced reforms in the legal and institutional frameworks for housing finance in a number of countries in the region.

5 See Renaud (1997, p. 13).
}

the direct housing subsidy (DHS) is to supplement the purchasing power of low-income families, a segment where the bulk of potential housing demand is concentrated, to allow these families to solve their housing problems through the market by purchasing a home that meets their goals and is compatible with their own efforts and economic possibilities. It is considered that demand subsidies are clearly more efficient than supply subsidies (in the form of Stateprovided housing), since they entail fewer losses in terms of the consumer's welfare, less detriment to the consumer's sovereignty and lower housing costs. ${ }^{6}$

The impact of direct housing subsidies on the purchasing power of beneficiaries is illustrated in figure $3 .^{7}$ To simplify the analysis, let us suppose that the consumption basket of the family in question is composed of two goods: housing and other goods. ${ }^{8}$ Given its level of (monthly) income, this family has a feasible consumption set represented by area АОВ and, based on its preferences, chooses, for example, basket $\mathrm{C}$ (it consumes OD in housing and OE in other goods). Suppose that this family receives a housing subsidy, by which its feasible consumption set increases and is now represented by the area AOFG. This produces an increase in the family's real income that shifts the budget line, now denoted by the line FG; this line is cut off at point G, since the subsidy can only be used to consume housing (the subsidy is not granted in cash and is therefore not fungible).

Figure 3 may well represent the case of a family receiving a direct housing subsidy under a housing leasing program (rental with commitment to purchase) such as the one in Chile. Since this is a subsidy granted by the State partially and regularly over time, the choice of the new consumption basket will most probably be located on section HI, since the subsidy can be added to the budget in order to purchase a better and more expensive house (point $\mathrm{H}$ ), or to free some of the budget used by the beneficiary family to pay rent, for the equivalent of the subsidy, in order to consume more of the other goods (point I) or a combination of the two (section $\mathrm{HI}$ ).

Direct housing subsidies have a number of advantages, but we will list only three here that are

\footnotetext{
${ }^{6}$ See Renaud (1997, pp. 3-4).

7 See Gonzales Arrieta (1999) for a detailed explanation of the economic rationale of direct housing subsidies.

8 According to Hicks's Composite Commodity Theorem, a group of goods whose relative prices do not vary may be treated as one commodity.
} 
FIGURE 3

Impact of a direct housing subsidy on real income

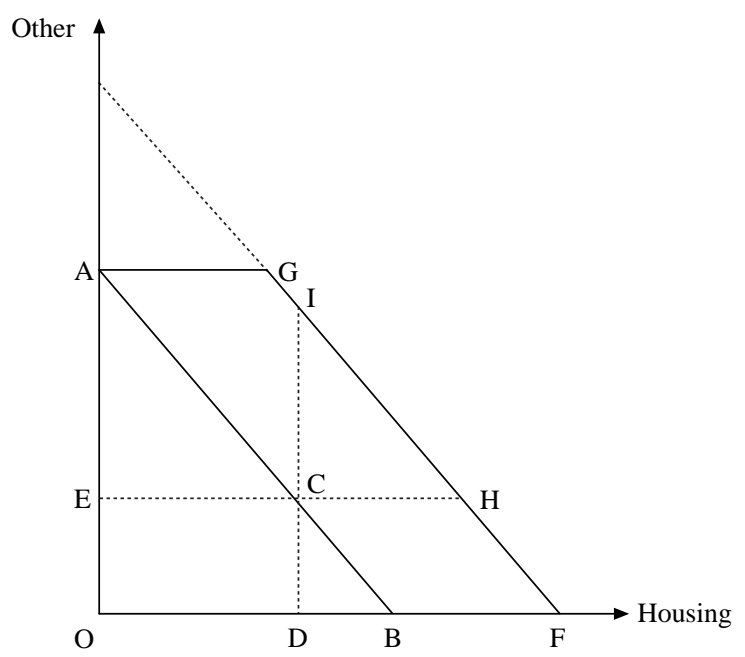

directly related to the development of the mortgage market. ${ }^{9}$ In the first place, these subsidies help to expand the potential market of mortgage borrowers, by reducing the amount of indebtedness needed to make up the price of the housing being purchased. They therefore allow recipient families, with no increase in their income, to obtain mortgage loans that meet their capacity to pay. In addition, the lower indebtedness made possible by these subsidies may stimulate the formal financial system to increase the volume of housing loans to the low-income sectors, and may also offer a better-quality loan portfolio: the borrowers are assuming obligations that will be easier to pay back, given their level of income, since the coverage of the mortgage guarantee will yield a surplus over the debt (equivalent to the amount of the subsidy).

Secondly, direct housing subsidies, as part of the above-mentioned tripartite scheme to facilitate access to housing, may stimulate the formation of family savings channelled through the formal financial system, if they are designed to reward the amount saved and the duration, steadiness and regularity of the prior saving process. This is true when regular prior saving is a requirement for granting such subsidies. In turn, the formation of prior savings through the financial system may help to expand the base of potential borrowers, incorporating groups that are traditionally rejected because of their inability to demonstrate a steady income.

Thirdly, direct housing subsidies, unlike interest rate subsidies, strengthen rather than distort the operation of the housing finance market. They complement, rather than displace, the mortgage loan on market terms; hence, for segments with some indebtedness capacity, the counterpart of a direct housing subsidy would be a mortgage transaction on the same terms. The validity of a subsidy mechanism of this type is therefore perfectly consistent with a housing resource mobilization scheme with positive real interest rates, both for savings and for loans, that stimulates both the flow of financial resources to the sector and the capitalization of financial intermediaries.

\section{III}

\section{Strengthening of mortgage instruments: policy recommendations}

\section{General overview in Latin America}

The validity and effectiveness of mortgage instruments are based on two premises: on the one hand, the

\footnotetext{
9 Direct housing subsidies have other important advantages, especially in terms of equity - they allow for better targeting and progressivity - and in terms of encouraging the efforts and capabilities of the beneficiaries to choose their housing solution. See Gonzales Arrieta (1999, pp. 142-143).
}

possibility of mobilizing long-term resources for housing finance and, on the other, the possibility of designing mortgage products that help families with indebtedness capacity gain access to housing.

Clearly, the mobilization of long-term resources for housing finance systems is a pending task in most Latin American countries. Countries like Brazil, with its former Housing Finance System (SFH); Colombia, with its now abolished system based on the constant unit of purchasing power (UPAC); Costa Rica, with its 
National Housing Finance System (sfNv); and the Dominican Republic, with the Dominican Savings and Loan System for Housing, to name only a few, primarily support long-term mortgage loans with resources, largely short-term, from the financial markets. The SFH in Brazil uses the so-called cadernetas de poupança, an instrument for raising savings deposits on call whose real growth, since 1981, has tended to be lower than non-monetary financial assets; moreover, these deposits have been very volatile, and a rigid scheme prevails for investing resources raised by this means. In Costa Rica, one of the main weaknesses of mutual-type savings and loan institutions, which are part of the SFNv, is the maturities mismatch between funding - mainly short-term family savings - and long-term lending. This traditional system of financing long-term loans with short-term savings is potentially vulnerable, because of the risk of mismatching maturities and rates.

Other countries rely on compulsory savings - for example, the Fondo de Garantía por Tiempo de Servicios [Unemployment Insurance Fund] (FGTS) in Brazil, or the payroll deductions in the Instituto del Fondo Nacional de Vivienda para los Trabajadores [National Workers' Housing Fund Institute] (INFONAVIT) and other funds in Mexico- or on the setting up of State-provided funds intermediated by the financial system, such as the Banco Ecuatoriano de la Vivienda [Ecuadorian Housing Bank] (BEv), the former Fondo de Operación y Financiamiento Bancario a la Vivienda [Bank Operation and Finance Fund for Housing] (FOvI) in Mexico, whose functions are now performed by the Sociedad Hipotecaria Federal [Federal Mortgage Company] (SHF), ${ }^{10}$ or the Fondo Mivivienda, the State housing programme in Peru. In addition to the constraints these mechanisms may impose on the amount of available resources, dependence on this type of resources often makes it difficult for lending institutions to sustain themselves. In Brazil, since FGTS deposits largely depend on variables such as employment level, purchasing power of wages and participation in formal employment, there has been an increased decapitalization of the Fund and some destabilization of housing credit in times of poor macroeconomic performance. In Peru, it is clear that the initial investment of the Fondo Mivivienda, including its loan repayments and profitability, will be

${ }^{10}$ Note that the ability of SHF to grant loans may not be extended beyond 12 October 2009. insufficient to meet the sustained needs for housing finance. ${ }^{11}$

Since housing finance and access to housing are only available through long-term loans to creditworthy families, the financial engineering of mortgage origination requires a transformation of maturities. Accordingly, linkages must be created between the housing finance market and the capital market, offering housing finance systems, in principle, the possibility of making resources available in amounts and terms that financial intermediation alone cannot provide. The development of a secondary mortgage market is the vehicle by which this linkage is established between the housing finance system and the capital market.

In Latin America a number of legal, institutional and operational initiatives are being taken to link housing finance systems with capital markets in order to attract long-term resources for housing. Where longterm resources (savings) and institutional investors exist, as they do in many countries to a greater or lesser extent, one way of achieving this goal is through mortgage securitization. To cite some examples, in Brazil the establishment of the Real Estate Finance System (SFI) clearly incorporates this idea; in Colombia the new law regulating sector development includes instruments to establish such linkages; in Mexico some legal reforms and the creation of the Sociedad Hipotecaria Federal [Federal Mortgage Company] (SHF) seek to create favourable conditions for securitization; and in Ecuador and Peru there is a legal framework and institutional setting to allow for securitization.

A crucial prerequisite for the development of secondary mortgage markets is the existence of sound primary markets to form the basis for the design of products to facilitate access to the capital market; also, it is required that the latter have long-term resources available. Experience in this area, however, shows that this process is only beginning - today only six countries in the region (Argentina, Brazil, Chile, Colombia, Mexico and Panama) have issued mortgagebacked securities - in part because of weaknesses in the primary mortgage markets themselves but also because of a series of difficulties, particularly the recent financial crises that have downgraded mortgage credit

\footnotetext{
${ }^{11}$ In line with this reality, the Fondo Mivivienda has been working on the design of a guarantee scheme and other products to stimulate resource mobilization from other sources, including the capital market.
} 
portfolios and created uncertainty for long-term financial investments. Mortgage securitization is not the only way, however, to establish linkages between the housing finance and capital markets. For many years Chile has been setting up these linkages through the use of mortgage securities, an instrument that dominates the Chilean mortgage market and is highly liquid, in addition to fully backing the assets and liabilities of the issuing institutions. In Chile, securitization is being used to create additional linkages with the capital market, an action that helps, in particular, to mitigate the risks of other instruments, such as endorsable mortgage credits and housing leasing contracts.

As noted above, there is a clear trend towards mobilizing the general saving of the economy for housing finance, that is, not only family savings in financial institutions but also the savings of institutional investors who participate in the capital markets. In order to continue competing in the financial market and start doing so in the capital market, the housing finance system must use instruments (such as deposits, mortgages and bonds) isolated from subsidy components. The need for housing finance systems to grant mortgage loans on market terms, without subsidies, is closely related to the possibilities for these systems to establish linkages with the capital markets, in order to broaden their fund-raising and improve risk management. Likewise, in order to strengthen the capacity of a housing finance system to attract more family savings through the financial system, these savings must earn a positive real rate of return, which not only prevents their depreciation over time, but also makes this option preferable to others. Such a condition would be incompatible with an arrangement whereby the institutions that attract family savings granted loans that included a subsidy, if the point is to ensure that housing finance instruments are self-sustainable in the long run.

In the light of the foregoing, in addition to providing long-term resources to the primary mortgage market, the criterion of profitability must prevail in order to ensure the emergence and permanence of mortgage credit. Amortization schemes must be designed to ensure the recovery of loans in real terms. This aim is important not only to rule out hidden subsidies, but also to prevent the decapitalization of intermediaries and to make it possible for portfolio recovery to be the primary source of resources for housing finance systems. In this context, various indexation models have been implemented in Latin America, in particular to counteract the adverse effects of inflation. To list some examples, Chile, Colombia and Mexico use an inflation-based scheme for indexed loans, while in Ecuador and Peru, mortgages are fully or primarily dollarized. On the other hand, Costa Rica and the Dominican Republic grant housing loans in local currency at variable rates.

While it is true that inflation is currently not a major economic problem in the region, any long-term financial instrument, such as a mortgage loan, will have better possibilities for success if it is associated with an indexation scheme that protects it against the risks of inflation and devaluation; in other words, that helps to "insure" it. Moreover, countries with a long tradition in the use of this scheme, such as Chile, are not even remotely considering the possibility of giving up indexation, despite a sustained period of price stability. Of course, no indexation system is a guarantee in the face of runaway inflation or devaluation; in fact, many of these schemes have failed in such situations. As for indexation, it has yet to be determined how to guard against or compensate for possible borrower default when wages fail to keep up with inflation (if indexation is inflation-based) or devaluation (if loans are dollarized).

The above-mentioned conditions, aimed at ensuring the profitability and self-sustainability of housing finance systems, should provide access to housing through a combination of prior saving and long-term mortgage loans. This does not necessarily mean, however, that all segments of the population, in particularly low-income groups, will have full access to the opportunities created by the operation of a housing finance system in such conditions. Therefore, in order to develop sound housing finance systems in developing societies with relatively low incomes and large segments with scant purchasing power, such as those prevailing in Latin America, ${ }^{12}$ it is essential to establish a clear separation between subsidies and financing. Attempts to use a housing finance mechanism that includes a subsidy (for example, on loan interest rates) in order to help low-income segments gain access to housing have generally not achieved the anticipated results and, on the contrary, have

\footnotetext{
12 ECLAC (2001) notes that $10 \%$ of higher-income households in Latin American and Caribbean countries earn, out of total income, an average of 19 times more than is earned by $40 \%$ of lower-income households. Moreover, between two thirds and three quarters of the population, depending on the country, earn a lower per capita income than the overall average. Thus, in the 1990s the region had the most unequal distribution of income in the world.
} 
undermined the self-sustainability of the housing finance system.

Accordingly, another pending task is to determine how to harmonize profitability criteria, which favour the development of a self-sustainable housing finance system, with the criterion of borrowers' access to housing and protection of their ability to pay. The available mortgage instruments in the housing finance markets of a number of countries are usually accessible to the relatively higher income strata but rarely help promote access for those with a limited capacity to pay. SHF loans in Brazil, where resources from short-term savings are used, are granted to upper-middle-income families (earning more than US\$1,000 a month). In Chile, where endorsable mortgage certificates are actively used for financing higher-priced housing, the average value of accumulated loans under this instrument, operated by endorsable mortgage loan administrators, was US $\$ 37,000$. About $37 \%$ of total loans granted by the Housing Finance Programme (PROFIVI) in Mexico, formerly administered by FOVI and now by SHF, go to households with ranges of monthly income between US\$ 780 and US\$1,300, and 35\% to those earning between US\$1,300 and US\$1,950. The average loan amount from the Fondo Mivivienda in Peru is about US $\$ 18,000$, which means that these funds are basically reaching families with monthly incomes of US\$ 530 to US\$ 585.

In public policy in Latin America there is, in fact, a fairly widespread tendency to recognize that a combination of saving and a mortgage loan (on market terms) is insufficient to meet the housing needs of large segments of the population, since for some time now nearly all the countries of the region have had direct housing subsidy schemes that represent a cornerstone of public policy and are designed to make up for the housing deficit in the low-income sectors.

\section{The role of the State in the creation of a mortgage market}

State participation is crucial to this pending task. For many years the State has been actively involved in the housing sector, seeking to help the low-income sectors; however, this State participation has often displaced the private sector and, ultimately, has failed to reach the target population. More recently, in Latin America there has been a tendency for the State to withdraw from the direct building and financing of housing, and to begin playing a basically regulatory role as well as promoting private initiative. Some experiences, such as those of Chile, Costa Rica, Ecuador and Mexico, bear witness to this change of focus and seem to indicate a move in the right direction. But these same experiences also reveal certain shortcomings: for example, in schemes of this nature it has not always been possible to attract private-sector participation in the granting of small mortgage loans. This means that in low-income societies, where broad sectors of the population have little purchasing power, the State is necessary not only to act as a regulator but also to help provide these sectors with greater access to housing. To ensure that this participation does not displace private initiative but rather reinforces the selfsustainability of housing finance systems, various instruments must be considered.

In general, in the case of low-income sectors, opportunities for access to housing should be based on a combination of up to three elements: (i) prior saving of the buyers, or some indication of their own effort, not necessarily monetary in nature, in the case of the lowest-income strata; (ii) a direct, non-reimbursable State subsidy, in support of housing demand; and (iii) a long-term mortgage loan on market terms as a supplement to help the more creditworthy strata. Obviously, while a combination of savings and a mortgage loan should be enough for families with sufficient capacity to pay to have access to housing, in the poorest sectors, with no capacity to pay, access to housing should fundamentally depend on State support in the form of a direct subsidy (for example, basic or partly self-built housing), with perhaps the addition of some component of saving or family effort.

From this standpoint, the direct housing subsidy mechanism should be used as leverage to convert the potential demand for housing into actual demand, without introducing distortions in the operation of the housing finance market; to that end, the portion of the housing market that lacks sufficient capacity to pay and needs a State subsidy must be differentiated from the portion having the capacity to pay, which can be reached by private intermediaries through market mechanisms. Furthermore, as already noted, the direct housing subsidy may contribute to the growth of the potential market of mortgage borrowers by reducing the amount of indebtedness needed to make up the price of the dwelling; the exception is the case of the poorest population, which can be offered a housing solution by combining prior saving with a State subsidy. A review of the experience in the region clearly shows that this mechanism is an integral part of the housing policies of a growing number of countries. 
Of course, the award of a direct housing subsidy is not enough to guarantee that private financial institutions will give supplementary mortgage loans to the beneficiary population or, more generally, to the lowest income strata. Moreover, the lack of mortgage credit to complement the State subsidy has undermined the effectiveness of the latter instrument, since it raises the proportion of subsidies that are granted but not paid out. In this context, the Latin American experience also sheds light on other promising channels of State intervention, provided that the purpose is not to distort the operation of the housing finance market. One of these, for example, is the mortgage loan scheme with preferential interest rates, as used by mortgage banks in Panama.

This mechanism works as follows: lenders originate mortgages at market interest rates, but qualify potential borrowers at preferential interest rates (i.e., below market rates) in order to give more families access to these loans. To cover the difference between the two rates, the Government grants the lenders tax credits that are tradable on a secondary market. Mortgages are originated at the referential rate, calculated and published by the National Banking Commission and based on the average mortgage rate offered by the five banks with the largest mortgage portfolios in the system. The mechanism is applied to mortgage loans of up to US\$ 62,500 in two tranches: the first is for housing worth up to US\$25,000, for which the Government guarantees the lender a 5\% reimbursement (in tax credits); the second tranche includes housing priced between US\$25,000 and US\$ 62,500, in which case the Government grants a $4 \%$ reimbursement. The financial intermediary applies to the Government for reimbursement at the end of the year, depending on the value of the mortgages granted. The borrower accordingly pays a preferential rate, defined as the difference between the referential (market) rate and the rate to be reimbursed by the Government (4 or 5\%, depending on the case). Employers may deduct the monthly payments from the borrowers' pay and then remit the payments to the lending institutions; this will help improve debt repayment, especially in the case of relatively small mortgage loans.

Note that, in this case, there is no borrower subsidy at the expense of the decapitalization of the lending institution, as has been (and still is) the usual practice in many countries. Actually, the institution grants mortgages at market rates, since the State covers the difference in rates with tradable tax credits.
Although the scheme is less progressive than the direct housing subsidy — since the bigger the loan, the bigger the subsidy - it has proved to be effective not only in stimulating mortgage loan activity in Panama, but also in creating a mortgage stock that is fully securitizable and attractive to the capital market. In other words, a product has been created in the primary mortgage market for the establishment of linkages with the capital market, in order to channel long-term resources to housing finance. In fact, in Panama a high proportion of the underlying assets in the issue of mortgagebacked securities is represented by loans originated under the Act on Preferential Interest Rates.

Another form of State intervention is the allocation of subsidies to financial institutions to cover the proportionately higher fixed costs they incur in granting and administering small mortgages. Although this mechanism should theoretically promote a greater availability of small mortgages for creditworthy families, it has only been applied in Chile, and for a short time. It is one of the innovations being applied under the new Chilean housing policy since early 2002, with a view to stimulating greater participation by private lenders in mortgage loans to supplement direct housing subsidies and also to relieve the State of the task of granting and administering small loans, in which it has a poor record. Low-income Chilean families have had limited access to the housing credit options offered in the market. ${ }^{13}$ In this situation, the State has acted, in practice, as an active mortgage lender for low-income segments that qualify for the Basic Housing Program of the Ministry of Housing and Urban Development (MINVU). Authors such as Pardo (1998) and Rojas (1999) found that the State's performance in this area was considered highly unsatisfactory. It is estimated that even after many renegotiations, more than $60 \%$ of the Ministry's mortgage portfolio includes more than three overdue payments, and default represents virtually three quarters of hidden subsidies. ${ }^{14}$

Furthermore, Latin American experience shows that State guarantees aimed at partially covering the credit risk involved in home mortgages may stimulate the participation of private-sector financial institutions. This type of guarantee is generally linked to State housing funds. In Mexico, sHF gives financial

\footnotetext{
${ }^{13}$ See Rojas and Greene (1995, pp. 31-49).

${ }^{14}$ See (Almarza (2000, pp. 237-257). Note that in Chile, beginning in 2002, an incentive policy has been applied to reduce past due indebtedness, which has had considerable success.
} 
intermediaries a guarantee against borrower default; if the borrower fails to pay, SHF covers the first loss for up to $25 \%$ of the unpaid debt, for which it charges a premium. Likewise, financial intermediaries operating with the Fondo Mivivienda in Peru receive credit risk coverage amounting to one third of the loan, being in addition a subordinated coverage (that is, the bank recovers its first two thirds, and the Fondo Mivivienda recovers the remaining third). Accordingly, as is being done in some countries, the possibility of establishing mortgage insurance in the region more widely should be explored, to protect lenders against potential losses as a result of default, on the one hand, and to enable borrowers to obtain mortgage loans with a lower down payment, on the other.

The proper management of inflation-indexed mortgages, or in some countries dollarized mortgages, given the intrinsic long-term horizon of mortgage loans, entails the requirement of ensuring adequate protection of the borrower's capacity to pay throughout the term of the loan. Thus it will also be important for the State to establish some kind of mechanism to compensate for any borrower's inability to pay resulting from the lag of wages behind inflation, where the latter is the indexation factor, or devaluation, where the loans are dollarized.

Since 1999, a type of mortgage has been used in Mexico with a guarantee against systemic risk that covers a possible sudden or permanent collapse in the minimum real wage, enabling borrowers to pay, in minimum wage terms, a mortgage denominated in investment units (UDI). ${ }^{15}$ The instrument devised to ensure that loan payments increase only in proportion to the minimum wage, even though the loan is denominated in investment units, is a swap, currently offered by SHF (formerly offered by FOVI) through the financial intermediaries. The cost of coverage is shared between the borrower and the Federal Government: the former pays a premium of 71 base points, which is combined with a bank line of credit backed by the Federal Government, creating a fund to cover temporary shortages of funds and guard against deep recessions. ${ }^{16}$ This fund is designed to withstand a real deterioration in wages of $25 \%$ for up to 30 years. If the deterioration is greater, SHF will have losses; if less, the fund will see a profit. This is a practical example

\footnotetext{
15 The investment unit (UDI) is a unit of account whose value is estimated by the Bank of Mexico (the country's central bank) and is adjusted daily according to inflation.

${ }^{16}$ See Zepeda (2000, pp. 30-35).
}

that combines State participation with the beneficiaries' commitment to sharing the cost of this type of insurance, adding a premium to the interest rate paid by the borrower.

Another step the State could take in order to promote the operation of a deeper mortgage market would be to act as a second-tier bank. Latin American experience reveals the ineffectiveness of the State as a direct lender: available funds have not reached the neediest population, and the coverage of these loans has not been very successful. On the other hand, the institutional schemes of second-tier banks, which exist in a number of countries in the region (Costa Rica, Ecuador, Mexico and Peru, among others), may be more efficient instruments for procuring resources for loan originators and stimulating the formation and consolidation of a housing finance market.

In Costa Rica, the Banco Hipotecario de la Vivienda (BANHVI) is a publicly-owned financial institution which acts as the leading agency for the National Housing Finance System (SFNV) as a secondtier bank. The strategy used in setting up SFNv was to combine a subsidy with an increased ability to purchase mortgages on the part of BANHVI, so that the financial intermediaries could commit themselves to substantial financing operations, thereby mitigating potential problems of liquidity and mismatch of maturities. In the first years of SFNV, the mortgage discount capacity of BANHVI not only represented one of the biggest sources of funds for savings and loan associations, but also accounted for a good part of the strength of the system. ${ }^{17}$ In the $1990 \mathrm{~s}$, however, funds became more scarce, and for nearly a decade BANHVI has virtually discontinued the use of this mechanism, making it more difficult to stimulate loan activity, especially for creditworthy sectors already receiving the subsidy.

For its part, the Banco Ecuatoriano de la Vivienda [Ecuadorian Housing Bank] (BEv) was restructured in 1998 and converted into a second-tier bank, geared to supporting the building and financing of housing by refinancing the mortgage portfolios of private-sector financial institutions, but no longer having a direct relationship with the final beneficiaries. After performing these functions for some years, BEv, as a second-tier bank, must now face the challenge of expanding its rediscount operations and reducing costs

\footnotetext{
17 From 1989 to 1992 , BANHVI completed an annual average of more than 7,000 mortgage rediscount operations. See Zawadzki (1994, p. 40).
} 
in order to become a source of funding capable of increasing the supply of mortgage credit.

In Mexico, SHF handles several credit products, acting as second-tier mortgage lender. These include lines of credit to financial intermediaries for housing purchase, although this scheme will expire in a few years. After the "tequila crisis" in 1994-1995, the socalled sociedades financieras de objeto limitado (SOFOLES), or specialized financial institutions, began to play an important role as mortgage institutions; today they channel nearly $96 \%$ of the funds granted by SHF, and also handle markets that previously had no access to mortgage loans from private financial intermediaries..$^{18}$ Note that, under the law creating it, SHF will retain the authority to grant loans only until 12 October 2009, after which it may influence the market only through the granting of guarantees. One function that SHF can perform (which its predecessor, FOVI, could not) is to help the sofoles finance themselves directly, through bank lines of credit or through the securities market, backed by a guarantee of timely payment granted by SHF.

This role as a second-tier lender entails, for example, the extension of lines of credit, including the contracting of external credits, a mortgage rediscount mechanism and the issue of mortgage securities in the capital market. Through this mechanism, it is generally possible to make a certain amount of funds available to the mortgage market on more favourable terms -in respect of maturities and cost - not only providing incentive to the participation of private lenders but also, in principle, reaching segments of the population with a more limited capacity to pay.

In addition to the above-mentioned ways of arranging for the State to act as a second-tier bank, as being practised to a greater or lesser extent in a number of countries in the region, the trend towards the creation of secondary mortgage markets - which is crucial, as we have seen, for ensuring the transformation of maturities required for housing finance- also expands State participation as a catalyst of the housing finance market. Many years ago, for example, the State played an important role in Chile as a market maker in the negotiation of mortgage securities. In the case of mortgage-backed securities, the State's actions may be crucial in promoting standardization in the primary mortgage market on the basis of incentives to encourage originators and other participating agents to meet

${ }^{18}$ See Obregón (2001, pp. 49-56). certain standards that will help to create a stock of securitizable mortgages. For example, since 1998 the Central Bank of the Argentine Republic has been encouraging the financial intermediaries to use a standardized contract to originate mortgages, while in Mexico, SHF, acting as guarantee provider, is promoting standardization of both documents and procedures for originating and collecting mortgage loans.

The provision of State guarantees supporting the issue of mortgage-backed securities and bonds, especially those including mortgages for low-income borrowers, may help to improve the creditworthiness of these instruments. In Colombia, this is the purpose of Titularizadora Colombiana, a secondary mortgage market institution; in Mexico, a prime role is assigned to SHF as an insurance provider for mortgage-backed issues; and in Peru, the fundamental law of the Fondo Mivivienda was amended to permit it to guarantee mortgage-related securities issued or managed by financial institutions or securitization companies.

Since the housing deficit in the low-income sectors is often qualitative in nature, these sectors accord high priority to improving existing housing. Housing finance needs are thus related to smaller loans on shorter terms, which do not necessarily have a mortgage as collateral. Accordingly, it may be helpful to promote micro-finance options that can be used to meet this type of credit needs. In the Dominican Republic, for example, some initiatives for granting micro-credits have emerged, administered by savings and loan associations, to improve housing in lowincome neighbourhoods. In addition, the Banco Nacional de Fomento de la Vivienda y la Producción [National Housing and Industrial Development Bank] (BNV) has established a micro-finance fund to improve and expand housing, whose funds will be channelled through non-governmental organizations that promote micro-credit, and through grassroots groups. The soundness of the financing will be based on managed, ongoing supervision, rather than on the existence of real guarantees; finance programmes will be offered to improve and repair housing, and hence small loans will be provided (US\$ 1,500 to US\$2,000 on average). Managed and cooperative self-construction housing schemes will also be promoted, operating on market terms, so that the existing resources in the formal sector can be applied in the informal sector. Although experiences of this type are still in the early stages in the Dominican Republic, and in general in the region, the financial product described has an enormous market potential; moreover, because these are short- and 
medium-term loans, there may be a better correspondence between the traditional modalities for raising and lending funds, and because there has been prior investment in a housing, the debt ratio is more favourable, if the property serves as collateral.

Finally, with the continuing aim of making housing loans more accessible to the low-income population, it is important to design products to stimulate prior saving for housing through the financial system in order to expand the base of potential borrowers by incorporating groups that are traditionally rejected because of their inability to demonstrate a steady income. In Chile, for example, the requirement of prior saving in order to qualify for a State subsidy has been a powerful tool in creating a significant volume of financial savings in small amounts. In Mexico, through regular savings plans, a financial history can be built that will allow the families involved to demonstrate their credit eligibility and, at the same time, make a down payment on the loan that will later be approved . More recently, in Peru, similar savings programmes have been set up as a prerequisite for applying for direct subsidy programs and supplementary loans. These programmes not only help to identify but also to "qualify" borrowers. In this way, a wide segment of the self-employed population, which represents a significant portion of the potential demand for housing, may be attracted to the mortgage market.
Almarza, S. (2000): Evaluación de los recursos en la política habitacional, in G. Crespo, P. Gross and others, Consulta sobre la política habitacional en Chile: informe final, Lima, InterAmerican Housing Union (UNIAPRAVI)

ECLAC (Economic Commission for Latin America and the Caribbean) (2001): Social Panorama of Latin America, 2000-2001, LC/G.2138-P, Santiago, Chile, September. United Nations publication, Sales No. E.01.II.G.141.

(2002): El crédito hipotecario y el acceso a la vivienda para los hogares de menores ingresos en América Latina, Financiamiento del desarrollo series, No. 122, LC/L.1779-P, Santiago, Chile, September. United Nations publication, Sales No. S.02.II.G.94

Forero, E. (2001): La financiación de vivienda en Colombia, document presented at the FEDELONJAS XX National Congress "El futuro de la vivienda en Colombia" (Bogotá, D.C., June 2001).

Gonzales Arrieta, G. (1999): Access to housing and direct subsidies: some Latin American experiences, CEPAL Review, No. 69, LC/G.2067-P, Santiago, Chile, December.

González, G. (2001): Nuevos instrumentos de acceso a la vivienda en Chile: el leasing habitacional, in G.M. Gonzales Arrieta (ed.), Mercados de capitales y financiamiento de la vivienda: la securitización en Chile, Lima, Inter-American Housing Union (UNIAPRAVI).

Hausmann, R. (1998): Perspectivas del financiamiento de vivienda en América Latina: una visión coyuntural y de largo plazo, Cuadernos, No. 179, July-September, Lima, Inter-American Housing Union (UNIAPRAVI).

Marez, M. (2000): Adapting risk management practices to the realities of the Mexican mortgage market, International Journal of Real Estate Finance, vol. 1, No. 2, Washington, D.C., Societas, November-December.

Obregón, C. (2001): Las sofoles como alternativa de financiamiento para la vivienda en México, La consolidación de los mercados financieros de vivienda en América Latina, Lima, InterAmerican Housing Union (UNIAPRAVI).

Pardo, C. (1998): Housing financing in Chile: the experience in primary and secondary mortgage financing, document presented at the IDB Conference "The development of mortgage securitization in Latin America and the Caribbean" (Washington, D.C., November 1998).

Renaud, B. (1997): Financial markets and the financing of social housing: a view from developing countries, document presented at the Conference on Social Housing Finance in the European Union (Nunspeet, Netherlands, February 1997)

Rojas, E. (1999): The long road to housing reform: lessons from the Chilean experience, Sustainable Development Department Best Practices Series, Washington, D.C., Inter-American Development Bank (IDB), July.

Rojas, E. and M. Greene (1995): Reaching the poor: lessons from the Chilean housing experience, Environment \& Urbanization, vol. 7, No. 2, London, International Institute for Environment and Development (IIED), October.

Varela, J.G. (2001): Instrumentos de financiamiento habitacional en el mercado primario chileno: letras de crédito hipotecario y mutuos hipotecarios endosables, in G.M. Gonzales Arrieta (ed.), Mercados de capitales y financiamiento de la vivienda: la securitización en Chile, Lima, Inter-American Housing Union (UNIAPRAVI)

Zawadzki, C. (1994): Nuevos modelos de financiamiento de vivienda en América Latina, Anales de la XXXI Conferencia Interamericana para la Vivienda, Lima, Inter-American Housing Union (UNIAPRAVI).

Zepeda, M. (2000): Innovaciones en la originación y administración de créditos hipotecarios: el caso del fovi de México, $\mathrm{La}$ vivienda y la gestión urbana: un desafío para el año 2000, Lima, Inter-American Housing Union (UNIAPRAVI). 